\title{
Determinant of Customer of Loyalty in Healthcare Industry : Mediating Role of Customer Trust
}

\author{
Endang Saefuddin Mubarok ${ }^{1}$, Arif Kurniawan ${ }^{2}$, Rahmat Hidayat ${ }^{3}$, \\ Ahman Kultur Hia ${ }^{4}$, Euis Bandawaty ${ }^{5}$ \\ ${ }^{123}$ Universitas Islam Jakarta \\ ${ }^{4}$ Pertiwi School of Economics \\ ${ }^{5}$ As-Syafi'iyah Islamic University \\ Correspondent: esmubarok@gmail.com ${ }^{1}$
}

\author{
Received : August 26, 2021 \\ Accepted : January 15, 2022 \\ Published : January 31, 2022
}

Citation: Mubarok, E. S., Kurniawan, A., Hidayat, R., Hia, A. K., \& Bandawaty, E. (2022). Determinant of Customer of Loyalty in Healthcare Industry : Mediating Role of Customer Trust. Ilomata International Journal of Management, 3(1),44-64.

https://doi.org/10.52728/ijim.v3i1.406

\begin{abstract}
This research aimed at understanding the effect of service quality, clinic image, and price/tariff on patient trust and loyalty. The multivariate analysis with descriptively and explanatorily-quantitative method was used for this research. The samples of the research were 120 respondents. Data collection was carried out using a questionnaire instrument and was subsequently analyzed by using Structural Equation Modeling (SEM). The results of this research concluded that the service quality and price/tariff had a significant effect on trust and clinic image had no significant effect on patient trust. The quality of service, clinic image, and price/tariff had a significant effect on patient loyalty, while trust had no significant effect on patient loyalty. Trust can mediate the effect of clinical image on patient loyalty. However, trust cannot mediate the effect of service quality and price/tariff on patient loyalty. The strength value of the dependent variable shown by the calculation of multiple correlation values (R2), both trust and patient loyalty are significant.
\end{abstract}

Keywords: image, service quality, price, trust, loyalty

\section{INTRODUCTION}

From just a managerial function, marketing has now transformed into a business philosophy and way of being oriented towards satisfying customers' needs and desires, as a consequence, it encourages companies to have a competitive advantage in a sustainable manner as well as to make contribution to the welfare of society and general environment. Changes in the market environment create opportunities as well as threats to the company's sustainability. There are five main, triggering factors for market changes viz. customers, company, competition, collaborators, and change (Kusumawardani et al., 2020; Minarti \& Segoro, 2014).

In order for companies to survive in the dynamics of market changes, there are several essential aspects that companies must obtain from customers-loyalty, trust, service quality, image, and price. Loyalty is basically the affection attached to a person for a product, service, and the people 
in it (Kotler \& Keller, 2016), which is indicated by repeated purchases tending to use the services of the same company only (Baliga et al., 2021), which is built on a long-term relationship between a person and another, between an individual and a company, and between a company and another company. Loyalty is built by trust service quality, corporate image, and price (Möller \& Parvinen, 2015; Olson et al., 2021)

Trust is a belief in integrity and ability of the organization, constituting the main basic capital in the transactional relationship of an entity. Trust is a collegial foundation to achieve a dream the company wants to achieve, and it generate a sustainable competitive advantage. Trust is an experiential process that takes time to form, which is based on a positive expectation of authority's actions and concerns (Sanjeev, 2017; Yucel-Aybat \& Hsieh, 2021).

In an effort to create customer trust and loyalty, the services provided by the company must be of high quality. Service quality is an attitude formed by a long-term and comprehensive evaluation of the company's performance, describing the condition of consumers by comparing the service they expect with what they receive, that consequently, the customers feel satisfied (Kopaneli, 2014; To et al., 2015).

Corporate image and corporate identity are two different things, but are closely related. Identity shows the identity of the corporate, while image is the public's perception about the corporate. Identity helps the corporate remind the public about the company's image. Corporate identity includes the brand and logo. Identity is built in a relatively short time, while the image must be built in a relatively long time. Identity is one of the important factors for the success of the corporate's image formation. Therefore, a good corporate identity will have a positive impact on image development (Nosi et al., 2021; Ruiz-Real et al., 2020).

Price is the value that consumers exchange for a benefit for consuming, using, or owning a product (Kotler \& Keller, 2016). Price is a means of communication with buyers. The price received by the buyer is the basis for comparison with other brands, and as a tool for obtaining market response (Olson et al., 2018).

An incorpartion of an organization is to achieve something that is expected, that as a consequence, organizational activities must be carried out properly. This research aims at conducting analysis efforts, collecting data and information related to the variables of service quality, corporate image, price, trust that affect customer loyalty (Dewsnap et al., 2020).

As explained above, loyalty is the affection attached to a person for a product, service, and people relevant to such product and service, which is indicated by repeated purchases tending to use the services of the same company only. Loyalty is built based on long-term relationships between an individual and another individual, between an individual and a company, and between a company and another company. With regard to brands, loyalty can be seen, at least in part, as a function of the frequency and regularity with a brand that has been chosen in the past. Loyalty has undergone four eras of thought change: (1) Loyalty is synonymous with customer satisfaction; (2) In building customer loyalty, the most important thing is to retain customers; (3) In obtaining customers, companies must be proactive; and (4) customer loyalty should not always be measured by the desire to repurchase, but rather spread the good news of the product to others (Kaur et al., 2018; Shi et al., 2018; Tseng \& Lee, 2018). 
The process of creating customer loyalty is the result of interpersonal relationships between customers and employees providing the services, built based on the foundation of long-term relationships. The types of relationships in retail are at different levels. Consumers form a distinct relationship with the store itself, and with the brands available within the store (Chang et al., 2014; Dewani et al., 2016; Prentice \& Correia Loureiro, 2017).

In building customer loyalty, there are two main factors that must be considered, namely attention to the value of the product produced, and building relationships with customers. Loyalty in a service transaction is highly dependent on the interpersonal relationships that occur. Customer loyalty is basically an obstacle for customers to switch to other brands. The efforts to prevent customers from continuing their switching habit are carried out, among others, by fostering a sense of loyalty in their mind by providing incentives (Cachero-Martínez \& VázquezCasielles, 2021; Lee \& Wong, 2021; Ozdemir et al., 2020)

Maintaining the customer loyalty is the most important factor to increase company profits, that therefore, obtaining loyal customers is the goal of almost all companies. Some of the things that underlie the company to continue to focus on customer loyalty programs are: (1) The larger the purchase volume, the lower the selling and distribution costs; (2) The positive image that is conveyed by mouth to mouth method to various parties; and (3) The customer's willingness to pay a higher price/rate commensurate with the value obtained (Dugar \& Chamola, 2021; Louis et al., 2021; White \& Tong, 2019).

Consumer loyalty classified into two categories-loyalty attitude and behavior. There are two approaches in each category, viz. behavioral and cognitive (attitudinal) approaches. The behavioral approach looks at consumers' repeat purchases of a brand. While the attitudinal approach is based on the idea that loyal consumers will show their commitment to the brand or company (Coelho et al., 2018; Kaur et al., 2018; Tseng \& Lee, 2018).

Trust is a dependent process that is based on a relevant but limited sample of experience, and is based on positive expectations of authority's actions and concerns. Thus, trust is created because of the relevant experience felt by the customer and the positive award given by the company. Trust refers to a person's positive expectations of others in a situation involving risks. Meaning, trust emphasizes the dependence of positive expectations and desires on the other party. For real companies, customer trust is one of the unobservable and intangible assets attracting business interest. The above definitions describes trust as a person's positive expectation in the form of a belief in him that other people, groups, or organizational authorities can fulfill his expectations (Chi et al., 2021; Hallikainen \& Laukkanen, 2018; Hartmann et al., 2015).

According to Lane (2001) in Suriadi (2014), in personal trust, there are three basic elements: (1) There are interdependence levels between the truster and the trustee; (2) Trust will provide a way to mitigate risk in an exchange relationship; and (3) the belief or expectation that the unfavorable outcome of accepting risk will not be taken advantage of by the other party in the relationship process. According to Sako (1997), there are three groups of trust-contractual trust, competence trust, and goodwill trust. 
Based on the understanding of mental calculation, with respect to how a person makes a decision to decide whether to believe or not to believe, Hurley (2006) created a model containing three factors which are the result of the complexity of the mix between personality, culture, and experience. The three factors are risk tolerance, level of adjustment; and relative power. In Hurley's view, there are seven factors related to aspects of the situation and the relationship between the two parties, viz., security, number of similarities, alignment of interest, benevolent concern, capability, predictability and integrity, level of communication.

In discussing the concept of trust, there are at least four key dimensions (Robbins and Judge, 2009) namely integrity, competence, consistency, and openness. While Casalo et al. (2007) suggested that trust is built on three aspects, viz., competence, honesty, and virtue.

Service quality is the consistency of products produced by the company that can meet the expectations and needs of internal customers such as employees, and external customers such as the community. The definition of service quality is based on the company's efforts to meet customer expectations, which includes three types of expectations: (1) Will expectation, the level of service performance that is expected to be obtained by the customer; (2) Should expectation, a reasonable level of service performance obtained by the customer, and (3) Ideal expectation, the ideal level of performance obtained by the customer. Customers compare the expected services to the perceived services. Service quality will depend on the company's ability in meeting the customers' expectations ( $\underline{\text { Kotler \& Keller, 2016). }}$.

During the 1980s, many studies were carried out both with the aim of knowing the factors affecting service quality, as well as determining the dimensions affecting service quality. Parasuraman et al. (1988) defines that the five dimensions in service quality are: (1) Reliability, the ability to service appropriately, and can be trusted; (2) Responsiveness, the willingness of employees to help and provide services required; (3) Assurance, having knowledge, ability, friendliness, politeness, and trustworthiness in personal contact; (4) Empathy, understanding consumer needs and difficulties, having good communication, personal attention, and ease in building communication; and (5) Tangibles, the availability of physical facilities, equipment and means of communication for the service process.

Meanwhile, according to Gronroos (1990), there are three dimensions of service quality: (1) Technical or outcome dimension, relevant to what consumers receive; (2) Functional or process related dimensions, relevant to how the service is delivered or presented; and (3) Corporate image, a dimension related to the company's image in consumers' point of view.

Corporate image and corporate identity are two different things, but closely related (Selame and Selame, 2000). Identity describes what actually exists in the company, or the identity that the company shows. The image shows the public's perception of the identity itself. Therefore, identity is not an image, but it can help companies remind people of their image.

Philosophically, image is a set of beliefs, ideas, and impressions that a person has about an object (Kotler and Keller (2012). In the view of LeBlanc and Nguyen (1996), the image has two main components: (1) Functional components, related to tangible characteristics that are easy to measure; and (2) the emotional concept, related to the psychological dimensions that are embodied in feelings and attitudes towards a company. 
The company's image needs to be popularized to the public through the promotion mix, especially in the intended target segment. Efforts to popularize the company's image are carried out through procedures for establishing, maintaining perceptions, and changing adverse perceptions. The image formed must reflect the real company's identity. However, although the image presented must be real, companies are not required to disclose their shortcomings.

The efforts of promoting the company's image through advertising have the main objectives namely, to build the awareness of the target segment towards the company, to form the public perception of the company's identity as desired, and to maintain that perception as long as possible. Corporate image advertising is basically an effort to prepare consumers to get to know the updated products or new products that the company will market (Gregory et al., 1999),

Building a corporate image is not only to get a positive perception from the public, but also to build the important, positive perception of the employees (Gray, 2005).

Business management experts suggest that employees should be the first target segment, and subsequently, the products may be marketed to the people outside the company. By building a positive and strong image among employees, companies can expect them to work with good performance and high loyalty. Image advertising to employees will not have much effect, if the employees' attitude towards the company is not favorable.

The corporate image becomes a guide for many people in making various decisions in buying products, because one person's perception is different from another. Therefore, the corporate image is not a single entity, however, it depends on the perceptions of each group of people, the type of their experiences and contacts with the company (LeBlanc and Nguyen, 1996). Different experiences and information perceived and received by each person will create different perceptions on each object, that as a consequence, the corporate image will be perceived differently by each person.

There are some reasons why the image becomes so important for a company (Gronroos, 1990), namely: (1) Sharing expectations with external marketing campaigns; (2) As a filter affecting the perception of the company's activities; (3) As a function of the experience and expectations of consumers on the quality of the company's services; and (4) Having an important influence on internal management.

Corporate image also has some benefits for companies in managing their business operations, among others: (1) Building competitiveness in the medium and long terms; (2) Protection during critical times; (3) Attractiveness to reliable executives; (4) Improving the effectiveness of marketing strategies; and (5) operational cost savings.

Corporate image is dynamic and complex (Chattananon and Lawley, 2007). With respect to service business, there are five things potentially affect the customers' perceptions on the image of a service company, viz. corporate identity, reputation, services performed, physical environment, and contact person.

Price is a monetary or non-monetary amount that contains certain utilities needed to obtain a product. Price is an expression of value related to product satisfaction and quality, the image formed through advertising and promotion, product availability through distribution networks, 
and services appertaining to them (Raymont Corey in Kartajaya et al., 2004). Price plays an important role for the economy, consumers and corporates. According to Kotler and Armstrong (1996), there are four measures characterizing the price, namely affordability, suitability of price with product, suitability of price with benefits, and competitiveness.

Price is one of the marketing mix elements requiring careful considerations. It is because price (Tjiptono et al, 2008) contains some strategic dimensions: (1) Price is a statement about the value of a product; (2) Price is what is obvious to buyers; (3) Price is the main determinant of demand; (4) Price is directly relevant to the company's revenues and profits; (6) Price can be adjusted quickly; (7) Price affects image and positioning strategy; and (8) Price is the number one problem the managers face.

In pricing, there are a number of central issues facing every organization: (1) What price should be set? (2) What is the basis for pricing? (3) Who should collect or accumulate the payments? (4) Where is the payment made? (5) When should payment be made, before or after delivery? (6) How are payments made? and (7) How to communicate the price to the target market?

Every company faced optional pricing programs. Broadly speaking, there are three types of pricing programs. First, penetration pricing, companies use low prices as the main basis for estimating demand. This type of pricing program is based on the following assumptions: (1) Market demand is elastic; (2) The company's demand is elastic, and competitors are not able to match the company's price level because of cost disanvantage; (3) The company sells products with a larger margin; (d) There are a large number of strong potential competitors; (5) There are external economies scales, that as a consequence, variable costs can be used to set the minimum prices; and (6) The purpose of pricing is to create primary demand or to create new customers.

The second is parity pricing, namely determining the prices that is the same or close to the competitor's price level. This type of pricing program is based on the following assumptions: (1) Market demand is inelastic, while company demand is elastic; (2) The company does not have any cost advantage over competitors; (3) There are no expected gains from economic scale, consequently, the lower price limit is based on fully allocated costs; and (4) The objective of pricing is to match the competitors'. The third is premium pricing, viz. determining the prices above competitors'. This type of pricing program is based on the following assumptions: (1) The company's demand is inelastic; (2) The company does not have any excess capacity; (3) There are very strong barriers to entry; (4) The advantages of economic scale are relatively small, that as a consequence, the full cost method is used to determine the minimum price; and (5) The objective of pricing is to attract new customers on the quality aspect.

\section{METHOD}

One of the factors influencing the customer trust is service quality (Kotler \& Keller, 2016; Zeithaml et al., 2018). This influence is also supported by the results of some studies (Ghaliyah \& Mubarok, 2017; Kim et al., 2017; Kurnianingrum \& Hidayat, 2020; Mubarok, 2019; Rizan et al., 2016). Based on the theory and research results above, the first hypothesis can be formulated as follows:

Hypothesis 1: Service quality significantly affects patient trust. 
Price is one of the factors influencing the customer trust as put forward by Kertajaya et al. (2004), Kotler and Armstrong (1996), and Tjiptono et al. (2008). This effect is also supported by the results of the study by Rizan et al. (2016), Kurnianingrum (2020), Hutama and Ekawati (2009), Suhaely and Darmoyo (2017), and Sari and Yasa (2019). Based on the theory and study results above, the second hypothesis can be formulated as follows:

Hypothesis 2: Price significantly affects patient trust.

Customer trust is influenced by corporate image as stated by Selame and Selame (2000), Gregory et al. (1999), and Kotler and Keller (2012). This statement is also supported by the results of studies conducted by Ghaliyah and Mubarok (2017), Suriadi (2014), Hutama and Ekawati (2009), Upamannyu et al. (2015); Suhaely and Darmoyo (2017), and Sari and Yasa (2019). Based on the theory and study results above, the third hypothesis can be formulated as follows:

Hypothesis 3: Corporate image significantly influences patient trust

As explained in the theory, service quality is one of the factors affecting customer loyalty. It is also supported by the results of the studies carried out by Fahrurozi (2021), Suriadi (2014), Sutanto and Japarianto (2013), Romadhoni et al. (2015), dan Ariani et al. (2019). Based on the theory and the results of the study, the fourth hypothesis is formulated as follows:

Hypothesis 4: Service quality significantly affects patient loyalty

In theory, it is stated that price is one of the factors affecting customer loyalty. The assumption is also supported by the results of studies by Fahrurozi (2021), Mubarok (2019), Riyadi (2016), Suriadi (2014), Ishaq (2012), and Setyono et al. (2015). Based on the theory and the results of the study, the fifth hypothesis is formulated as follows:

Hypothesis 5: Price significantly affects patient loyalty

Likewise, theoretically it is stated that corporate image is one of the factors affecting the customer loyalty. This is also supported by the results of studies carried out by Wantara and Tambrin (2019) study, Sutanto and Japarianto (2013), Setrianimatina et al. (2018), Hayu (2014), and Ariani et al. (2019). Based on the theory and results of study above, the sixth hypothesis is formulated as follows:

Hypothesis 6: Corporate image significantly affects patient loyalty

One of the factors influencing customer loyalty is trust, as stated by Robbins and Judge (2009), Colquitt et al. (2009), NcShane and Glinow (2008), and Hurley (2006). This is also supported by the results of studies by Wikantari (2020), Suriadi (2014), Rahayu (2015), Jain et al. (2014), and Vauren et al. (2012), Ghasemi and Beiranvand (2016) and Hayu (2014). Based on the theory and the results of the study, the seventh hypothesis is formulated as follows:

Hypothesis 7: Trust significantly affects patient loyalty

Meanwhile, the future hypotheses, viz. the ninth and tenth ones proposed in this study can be formulated as follows:

Hypothesis 8: Service quality has a significant effect on patient loyalty mediated by trust. 
Hypothesis 9: Price has a significant effect on patient loyalty mediated by trust.

Hypothesis 10: Corporate image has a significant effect on patient loyalty mediated by trust.

The descriptively and explanatorily-quantitative method was used for this research. The population in this study are health service users who are recorded every day in the database of Karya Bhakti Dipa Jakarta Clinic, with a total sample of 120 respondents. For this research, statistical analysis technique, Structural Equation Modeling (SEM) was used based on Partial Least Square (PLS) method. This SEM-PLS method was used on limited samples and non-strict data assumptions (Hair, et al, 2010). Since SEM-PLS does not include the significance test directly, the significance level is determined by using bootstrapping assistance.

\section{RESULTS AND DISCUSSION}

To show the results of this study, the analysis of the influence between variables was carried out through five stages, namely: evaluation of the SEM model, evaluation of the measurement model (outer model), evaluation of the structural model (inner model, hypothesis testing, and mediation testing.

\section{EVALUATION OF SEM MODEL}

Structural Equation Modeling (SEM) is a set of statistical techniques that allow the simultaneous testing of a relatively complex set of relationships. This complicated relationship can be interpreted as a series of relationships built between one or several endogenous (dependent) variables with one or more exogenous (independent) variables, where each endogenous and exogenous variable is in the form of a factor (construct) built from several indicators that are directly observed. (Waluyo, 2016).

SEM is also known as Path Analysis or Confirmatory Factor analysis. SEM, as an analytical tool, is able to answer problems that are correlational, regressive, and can identify the dimensions of a concept (dimensional), so that SEM can be said to be a combination of multiple regression factor analysis. In building a research model, it must be based on theoretical justification or a strong reasoning process so that the factor analysis that applies in SEM is confirmatory factor analysis because it aims to confirm whether the indicators used must have a theoretical footing so that they can confirm the constructs or variables (Waluyo, 2016).

\section{MEASUREMENT MODEL (OUTER MODEL)}

The outer model describes the specification of the relationship between latent variables and the indicators. In other words, the outer model explains how each indicator affects the latent variables. To check whether the indicators of every construct can measure what should be measured or not, it is necessary to carry out the convergent validity and discriminant validity test. 


\section{CONVERGENT VALIDITY}

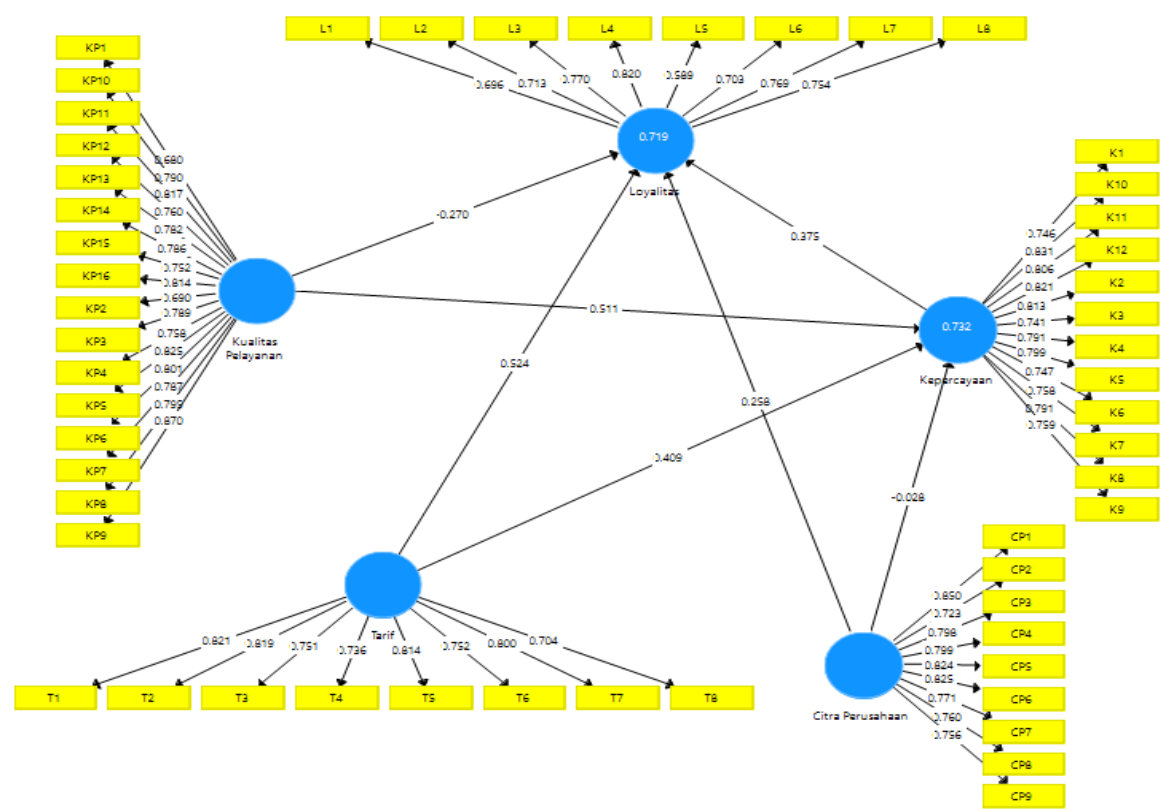

Figure 1: PLS Algorithm Items and Latent Variables (Stage 1)

Table 1: Loading Factor Value of All Items (Stage 1)

\begin{tabular}{|c|c|c|c|}
\hline Items & Loading & Items & Loading \\
\hline SQ1 ${ }^{1} \leftarrow$ Service Quality & 0.680 & T1 $\leftarrow$ Tariff & 0.821 \\
\hline SQ10 $\leftarrow$ Service Quality & 0.790 & T2 $\leftarrow$ Tariff & 0.819 \\
\hline SQ11 $\leftarrow$ Service Quality & 0.817 & T3๘ Tariff & 0.751 \\
\hline SQ12 $\leftarrow$ Service Quality & 0.760 & T4 $\leftarrow$ Tariff & 0.736 \\
\hline SQ13 $\leftarrow$ Service Quality & 0.782 & T5 $\leftarrow$ Tariff & 0.814 \\
\hline SQ14 $\leftarrow$ Service Quality & 0.786 & T6 $\leftarrow$ Tariff & 0.752 \\
\hline SQ15 $\leftarrow$ Service Quality & 0.752 & T7 $\leftarrow$ Tariff & 0.800 \\
\hline SQ16 $\leftarrow$ Service Quality & 0.814 & T8๘ Tariff & 0.704 \\
\hline SQ2 $\leftarrow$ Service Quality & 0.690 & $\operatorname{Tr} 1^{2} \leftarrow$ Trust & 0.746 \\
\hline SQ3 $\leftarrow$ Service Quality & 0.789 & $\operatorname{Tr} 10 \leftarrow$ Trust & 0.831 \\
\hline 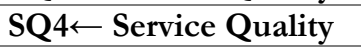 & 0.758 & Tr11 $\leftarrow$ Trust & 0.806 \\
\hline SQ5 $\leftarrow$ Service Quality & 0.825 & $\operatorname{Tr} 12 \leftarrow$ Trust & 0.821 \\
\hline SQ6 $\leftarrow$ Service Quality & 0.801 & Tr2 & 0.813 \\
\hline SQ7 $\leftarrow$ Service Quality & 0.787 & Tr3๘ Trust & 0.741 \\
\hline SQ8 $\leftarrow$ Service Quality & 0.795 & Tr4 4 Trust & 0.791 \\
\hline SQ9๘ Service Quality & 0.870 & Tr5 5 Trust & 0.799 \\
\hline $\mathrm{CI}^{3}{ }^{2} \leftarrow$ Corporate Image & 0.850 & $\operatorname{Tr} 6 \leftarrow$ Trust & 0.747 \\
\hline CI2 $\leftarrow$ Corporate Image & 0.723 & $\operatorname{Tr} 7 \longleftarrow$ Trust & 0.758 \\
\hline $\mathrm{CI} 3 \longleftarrow$ Corporate Image & 0.798 & Tr8 $\leftarrow$ Trust & 0.791 \\
\hline CI4־Corporate Image & 0.799 & Tr9־ Trust & 0.759 \\
\hline CI5 Corporate Image & 0,824 & L1 $\leftarrow$ Loyalty & 0.696 \\
\hline CI6 Corporate Image & 0.825 & L2 $\leftarrow$ Loyalty & 0.713 \\
\hline CI7 Corporate Image & 0.771 & L3๘ Loyalty & 0.770 \\
\hline CI8 $\leftarrow$ Corporate Image & 0.760 & L4ヶ Loyalty & 0.820 \\
\hline \multirow{4}{*}{ CI9 $\leftarrow$ Corporate Image } & 0.756 & L5 Loyalty & 0.589 \\
\hline & & L6 $\leftarrow$ Loyalty & 0.703 \\
\hline & & L7 $\leftarrow$ Loyalty & 0.769 \\
\hline & & L8 $\leftarrow$ Loyalty & 0.754 \\
\hline
\end{tabular}

\footnotetext{
${ }^{1} \mathrm{KP}($ Kepuasan Pelanggan $)=\mathrm{SQ}$ (Service Quality $)$

${ }^{2} \mathrm{~K}($ Kepercayaan $)=\operatorname{Tr}($ Trust $)$
} 
After reprocessing, not all of them have a loading factor value above 0.7 , viz. loyalty 2 and loyalty6 items (Figure 2 and Table 2). Therefore, reprocessing will be carried out without including all items that have been removed from the model.

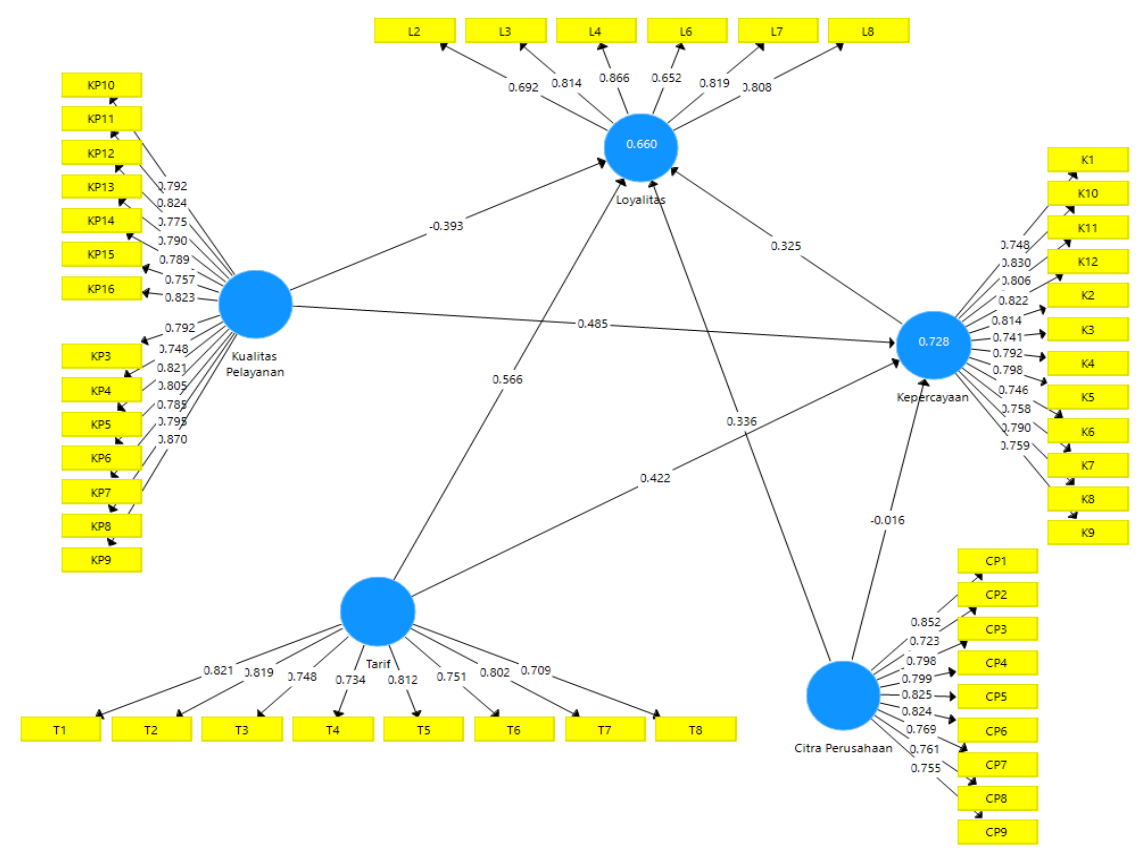

Figure 2: PLS Algorithm Items and Latent Variables (Stage 2)

Table 2: Loading Factor Values of All Items (Stage 2)

\begin{tabular}{|c|c|c|c|}
\hline Items & Loading & Items & Loading \\
\hline SQ10 Service Quality & 0.792 & T4 $\leftarrow$ Tariff & 0.734 \\
\hline SQ11 $\leftarrow$ Service Quality & 0.824 & T5 $\leftarrow$ Tariff & 0.812 \\
\hline SQ12 $\leftarrow$ Service Quality & 0.775 & T6๘ Tariff & 0.751 \\
\hline SQ13 $\leftarrow$ Service Quality & 0.790 & T7 $\leftarrow$ Tariff & 0.802 \\
\hline SQ14 $\leftarrow$ Service Quality & 0.789 & T8 $\leftarrow$ Tariff & 0.709 \\
\hline SQ15 $\leftarrow$ Service Quality & 0.757 & $\operatorname{Tr} 1 \leftarrow$ Trust & 0.748 \\
\hline SQ16 $\leftarrow$ Service Quality & 0.823 & Tr10 $\leftarrow$ Trust & 0.830 \\
\hline SQ3 $\leftarrow$ Service Quality & 0.792 & Tr11 $\leftarrow$ Trust & 0.806 \\
\hline SQ4 $\leftarrow$ Service Quality & 0.748 & $\operatorname{Tr} 12 \leftarrow$ Trust & 0.822 \\
\hline SQ5 $\leftarrow$ Service Quality & 0.821 & $\operatorname{Tr} 2 \leftarrow$ Trust & 0.814 \\
\hline SQ6 $\leftarrow$ Service Quality & 0.805 & $/ \operatorname{Tr} 3 \leftarrow$ Trust & 0.741 \\
\hline SQ7 $\leftarrow$ Service Quality & 0.785 & $\operatorname{Tr} 4 \leftarrow$ Trust & 0.792 \\
\hline SQ8 $\leftarrow$ Service Quality & 0.795 & $\operatorname{Tr} 5 \leftarrow$ Trust & 0.798 \\
\hline SQ9๘ Service Quality & 0.870 & $\operatorname{Tr} 6 \leftarrow$ Trust & 0.746 \\
\hline $\mathrm{CI} 1^{3} \leftarrow$ Corporate Image & 0.852 & $\operatorname{Tr} 7 \leftarrow$ Trust & 0.758 \\
\hline CI2 Corporate Image & 0.723 & Tr8 $\leftarrow$ Trust & 0.790 \\
\hline CI3 $\leftarrow$ Corporate Image & 0.798 & $\operatorname{Tr} 9 \leftarrow$ Trust & 0.759 \\
\hline CI4־Corporate Image & 0.799 & L2๘Loyalty & 0.692 \\
\hline CI5 $\leftarrow$ Corporate Image & 0.825 & 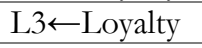 & 0.814 \\
\hline CI6 $\leftarrow$ Corporate Image & 0.824 & L4«Loyalty & 0.866 \\
\hline CI7 $\leftarrow$ Corporate Image & 0.769 & L6־Loyalty & 0.652 \\
\hline CI8 $\leftarrow$ Corporate Image & 0.761 & L7๘Loyalty & 0.819 \\
\hline CI9־Corporate Image & 0.755 & L8๘Loyalty & 0.808 \\
\hline T1 $\leftarrow$ Tariff & 0.821 & & \\
\hline T2 $\leftarrow$ Tariff & 0.819 & & \\
\hline T3 $\leftarrow$ Tariff & 0.748 & & \\
\hline
\end{tabular}

${ }^{3} \mathrm{CP}($ Citra Perusahaan $)=\mathrm{CI}($ Corporate Image $)$ 


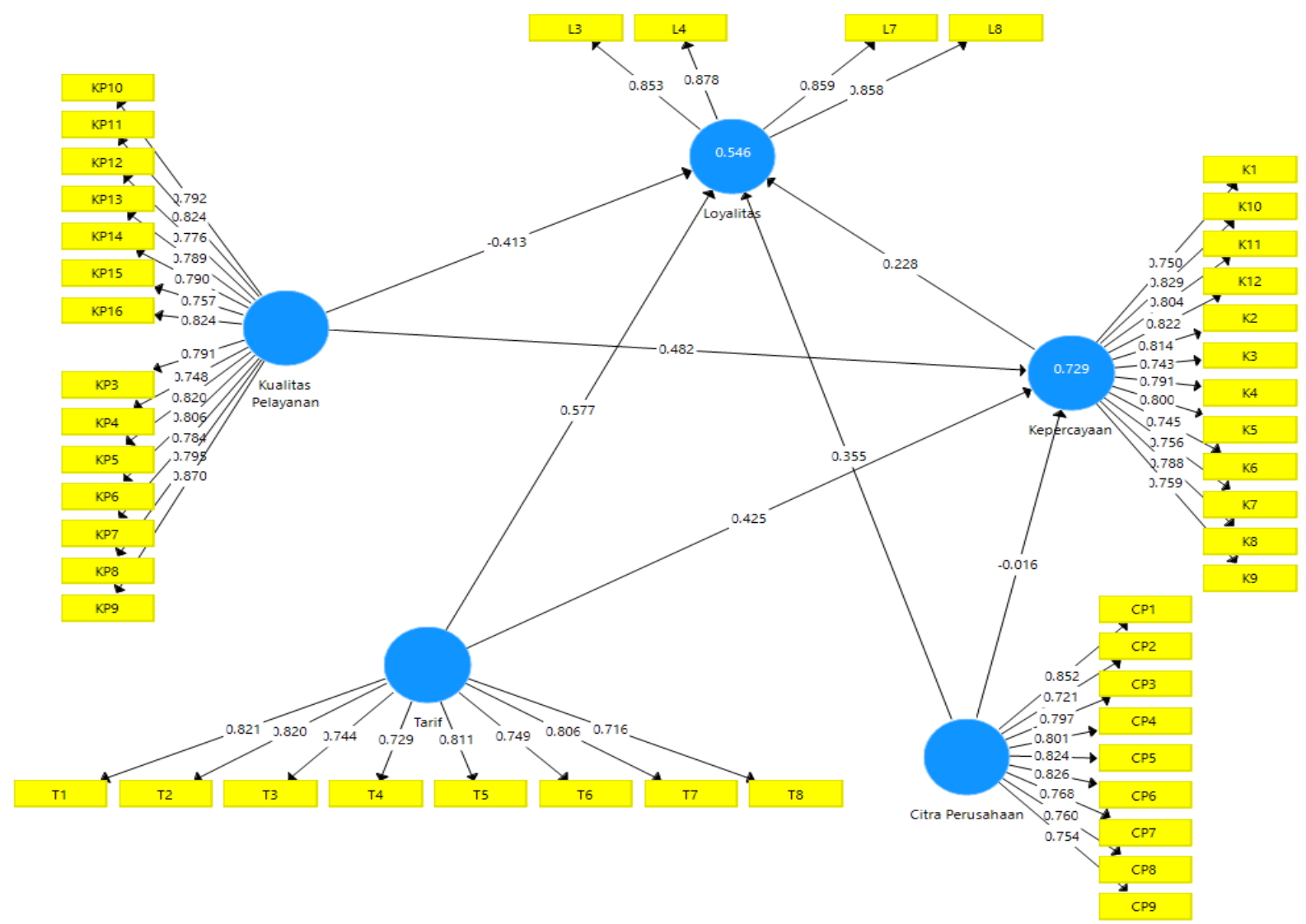

Figure 3: PLS Algorithm Items and Latent Variables (Stage 3)

The results of the second stage of data processing were subsequently processed in stage three. After the reprocessing, the loading factor values were all above 0.7 (Figure 3 and Table 3 ).

Table 3: Loading Factor Values of All Items (Stage 3)

\begin{tabular}{|c|c|c|c|}
\hline Items & Loading & Items & Loading \\
\hline SQ10 $\leftarrow$ Service Quality & 0.792 & T1 $\leftarrow$ Tariff & 0.821 \\
\hline SQ11 $\leftarrow$ Service Quality & 0.824 & T2 $\leftarrow$ Tariff & 0.820 \\
\hline SQ12 $\leftarrow$ Service Quality & 0.776 & 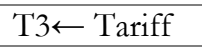 & 0.744 \\
\hline SQ13 $\leftarrow$ Service Quality & 0.789 & T4 $\leftarrow$ Tariff & 0.729 \\
\hline SQ14 $\leftarrow$ Service Quality & 0.790 & T5 $\leftarrow$ Tariff & 0.811 \\
\hline SQ15 $\leftarrow$ Service Quality & 0.757 & T6 $\leftarrow$ Tariff & 0.749 \\
\hline SQ16 $\leftarrow$ Service Quality & 0.824 & T7 $\leftarrow$ Tariff & 0.806 \\
\hline SQ3 $\leftarrow$ Service Quality & 0.791 & 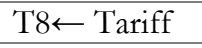 & 0.716 \\
\hline 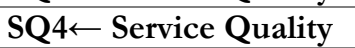 & 0.748 & Tr1 $\leftarrow$ Trust & 0.792 \\
\hline 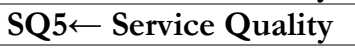 & 0.820 & $\operatorname{Tr} 10 \leftarrow$ Trust & 0.824 \\
\hline SQ6 $\leftarrow$ Service Quality & 0.806 & Tr11 $\leftarrow$ Trust & 0.776 \\
\hline SQ7 $\leftarrow$ Service Quality & 0.784 & $\operatorname{Tr} 12 \leftarrow$ Trust & 0.789 \\
\hline SQ8 $\leftarrow$ Service Quality & 0.795 & $\operatorname{Tr} 2 \longleftarrow$ Trust & 0.790 \\
\hline SQ9 & 0.870 & $\operatorname{Tr} 3 \leftarrow$ Trust & 0.757 \\
\hline CI1 $\leftarrow$ Corporate Image & 0.852 & $\operatorname{Tr} 4 \leftarrow$ Trust & 0.824 \\
\hline CI2 $\leftarrow$ Corporate Image & 0.721 & $\operatorname{Tr} 5 \leftarrow$ Trust & 0.791 \\
\hline CI3 $\leftarrow$ Corporate Image & 0.797 & Tr6 $\leftarrow$ Trust & 0.748 \\
\hline CI4 $\leftarrow$ Corporate Image & 0.801 & $\operatorname{Tr} 7 \leftarrow$ Trust & 0.820 \\
\hline CI5 $\leftarrow$ Corporate Image & 0.824 & Tr8 $\leftarrow$ Trust & 0.806 \\
\hline CI6 $\leftarrow$ Corporate Image & 0.826 & $\operatorname{Tr} 9 \longleftarrow$ Trust & 0.784 \\
\hline
\end{tabular}


Determinant of Customer of Loyalty in Healthcare Industry : Mediating Role of Customer Trust Mubarok, Kurniawan, Hidayat, Hia, Bandawaty

\begin{tabular}{|c|c|c|c|}
\hline CI7 & 0.768 & L3 $\leftarrow$ Loyalty & 0.853 \\
\hline CI8 $\leftarrow$ Corporate Image & 0.760 & L4ヶ Loyalty & 0.878 \\
\hline CI9 $\leftarrow$ Corporate Image & 0.754 & L7ヶ Loyalty & 0.859 \\
\hline & & L8 $\leftarrow$ Loyalty & 0.858 \\
\hline
\end{tabular}

The construct reliability was examined by using two measures, viz. Composite Reliability (CR) and Average Variance Extracted (AVE). The threshold of a good CR was above 0.6 and above 0.5 for AVE (Bagozzi and Yi, 1991).

Table 4: Composite Reliability Value and AVE

\begin{tabular}{lll}
\hline Constructs & Composite Reliability & AVE \\
\hline Corporate Image & 0.937 & 0.625 \\
\hline Trust & 0.950 & 0.615 \\
\hline Service Quality & 0.961 & 0.637 \\
\hline Loyalty & 0.920 & 0.743 \\
\hline Tariff & 0.923 & 0.601 \\
\hline
\end{tabular}

The table above shows all construct values for both CR and AVE that are above the threshold values, namely 0.6 and 0.5 that as a consequence, the conclusion is that the constructs are sufficient. Based on the results obtained, it could be concluded that there was no convergent validity problem in the model being tested. Therefore, the next test can be carried out, viz. the discriminant validity test.

\section{DISCRIMINANT VALIDITY}

Discriminant validity of construct items was examined by using the cross-loadings (Vinzi et al., 2010). The cross-loading value was obtained by calculating the correlation between the score components of every latent variable with each indicator block and all items in the model. The cross-loading value was the correlation between each construct and the items of each construct. The correlation between constructs and items was compared to the correlation between items and other constructs. If the construct indicator correlation has a higher value than the indicator correlation with other constructs, it is said that the construct has a high discriminant validity.

Table 5 shows that the loading value of every item for its construct is higher than the value of cross-loading with other constructs. Based on the results of the cross-loading analysis, it appears that there is no discriminant validity problem. The output of SmartPLS for the construct of cross-loading and the items are as follows:

Table 5: Cross Loading

\begin{tabular}{llllll}
\hline & $\begin{array}{l}\text { Corporate } \\
\text { Image }\end{array}$ & Trust & $\begin{array}{l}\text { Service } \\
\text { Quality }\end{array}$ & Loyalty & Tariff \\
\hline CP1/CI1 & $\mathbf{0 . 8 5 2}$ & 0.697 & 0.775 & 0.596 & 0.692 \\
\hline /CI2 & $\mathbf{0 . 7 2 1}$ & 0.514 & 0.643 & 0.361 & 0.513 \\
\hline $\mathbf{C I 3}$ & $\mathbf{0 . 7 9 7}$ & 0.588 & 0.707 & 0.465 & 0.651 \\
\hline $\mathbf{C I} 4$ & $\mathbf{0 . 8 0 1}$ & 0.600 & 0.692 & 0.599 & 0.659 \\
\hline $\mathbf{C I 5}$ & $\mathbf{0 . 8 2 4}$ & 0.667 & 0.767 & 0.554 & 0.732 \\
\hline $\mathbf{C I 6}$ & $\mathbf{0 . 8 2 6}$ & 0.623 & 0.727 & 0.514 & 0.665 \\
\hline $\mathbf{C I 7}$ & $\mathbf{0 . 7 6 8}$ & 0.522 & 0.658 & 0.421 & 0.642 \\
\hline $\mathbf{C I 8}$ & $\mathbf{0 . 7 6 0}$ & 0.658 & 0.688 & 0.510 & 0.655 \\
\hline
\end{tabular}


Determinant of Customer of Loyalty in Healthcare Industry : Mediating Role of Customer Trust Mubarok, Kurniawan, Hidayat, Hia, Bandawaty

\begin{tabular}{|c|c|c|c|c|c|}
\hline CI9 & 0.754 & 0.539 & 0.678 & 0.456 & 0.647 \\
\hline K1.Tr1 & 0.638 & 0.750 & 0.630 & 0.513 & 0.694 \\
\hline Tr10 & 0.678 & 0.829 & 0.748 & 0.473 & 0.657 \\
\hline Tr11 & 0.624 & 0.804 & 0.670 & 0.474 & 0.619 \\
\hline $\operatorname{Tr} 12$ & 0.627 & 0.822 & 0.670 & 0.480 & 0.664 \\
\hline Tr2 & 0.617 & 0.814 & 0.670 & 0.583 & 0.686 \\
\hline Tr3 & 0.532 & 0.743 & 0.574 & 0.597 & 0.649 \\
\hline Tr4 & 0.641 & 0.791 & 0.642 & 0.575 & 0.598 \\
\hline Tr5 & 0.615 & 0,800 & 0,710 & 0,455 & 0,680 \\
\hline Tr6 & 0.567 & 0.745 & 0.621 & 0.504 & 0.596 \\
\hline $\operatorname{Tr} 7$ & 0.591 & 0.756 & 0.592 & 0.375 & 0.530 \\
\hline /Tr8 & 0.552 & 0.788 & 0.583 & 0.469 & 0.600 \\
\hline Tr9 & 0.513 & 0.759 & 0.588 & 0.379 & 0.640 \\
\hline KP10/SQ10 & 0.754 & 0.657 & 0.792 & 0.461 & 0.688 \\
\hline SQ11 & 0.714 & 0.682 & 0.824 & 0.462 & 0.677 \\
\hline SQ12 & 0.645 & 0.629 & 0.776 & 0.453 & 0.669 \\
\hline SQ13 & 0.672 & 0.662 & 0.789 & 0.383 & 0.632 \\
\hline SQ14 & 0.765 & 0.640 & 0.790 & 0.460 & 0.702 \\
\hline SQ15 & 0.753 & 0.620 & 0.757 & 0.415 & 0.629 \\
\hline SQ15 & 0.795 & 0.644 & 0.824 & 0.493 & 0.651 \\
\hline SQ3 & 0.739 & 0.704 & 0.791 & 0.446 & 0.683 \\
\hline SQ4 & 0.616 & 0.609 & 0.748 & 0.431 & 0.575 \\
\hline SQ5 & 0.703 & 0.725 & 0.820 & 0.493 & 0.659 \\
\hline SQ6 & 0.681 & 0.658 & 0.806 & 0.466 & 0.633 \\
\hline SQ7 & 0.691 & 0.630 & 0.784 & 0.469 & 0.664 \\
\hline SQ8 & 0.657 & 0,588 & 0,795 & 0,433 & 0,637 \\
\hline SQ9 & 0.782 & 0.701 & 0.870 & 0.481 & 0.750 \\
\hline L3 & 0.561 & 0.520 & 0.471 & 0.853 & 0.616 \\
\hline L4 & 0.616 & 0.644 & 0.591 & 0.878 & 0.719 \\
\hline L7 & 0.500 & 0.475 & 0.453 & 0.859 & 0.528 \\
\hline L8 & 0.504 & 0.507 & 0.425 & 0.858 & 0.566 \\
\hline T1 & 0.760 & 0.667 & 0.756 & 0.538 & 0.821 \\
\hline T2 & 0.707 & 0.629 & 0,629 & 0.608 & 0.820 \\
\hline T3 & 0.641 & 0.612 & 0.637 & 0.440 & 0.744 \\
\hline T4 & 0.547 & 0.555 & 0.579 & 0.500 & 0.729 \\
\hline T5 & 0.715 & 0,715 & 0.736 & 0.497 & 0.811 \\
\hline T6 & 0.600 & 0.580 & 0.579 & 0.543 & 0.749 \\
\hline T7 & 0.577 & 0.687 & 0.623 & 0.646 & 0.806 \\
\hline T8 & 0.579 & 0,574 & 0,596 & 0,626 & 0,716 \\
\hline
\end{tabular}

Discriminant validity could be tested by comparing the AVE square root value to the correlation value between constructs (Ghozali, 2008). The table below shows the calculation results.

Table 6: Correlation Between Latent Variables and AVE Square Root

\begin{tabular}{llllll}
\hline & $\begin{array}{l}\text { Corporate } \\
\text { Image }\end{array}$ & Trust & $\begin{array}{l}\text { Service } \\
\text { Quality }\end{array}$ & Loyalty & Tariff \\
\hline $\begin{array}{l}\text { Corporate } \\
\text { Image }\end{array}$ & $\mathbf{0 . 7 9 0}$ & & & & \\
\hline Trust & 0.766 & $\mathbf{0 . 7 8 4}$ & & & \\
\hline $\begin{array}{l}\text { Service } \\
\text { Quality }\end{array}$ & 0.773 & 0.760 & $\mathbf{0 . 7 9 8}$ & & \\
\hline Loyalty & 0.638 & 0.629 & 0.569 & $\mathbf{0 . 8 6 2}$ & \\
\hline Tariff & 0.727 & 0.762 & 0.729 & 0.713 & $\mathbf{0 . 7 7 5}$ \\
\hline
\end{tabular}


Table 6 indicates that the square root value of AVE (main diagonal) is higher than the correlation of every constructs so that it can be said there is no problem regarding the discriminant validity. Therefore, the next step, namely the evaluation of the structural model, can be done.

\section{STRUCTURAL MODEL EVALUATION (INNER MODEL)}

One of the evaluations of structural model was to observe the strength of the independent variables of the whole model. The strength of the independent variable was examined by observing the square of the multiple correlation $\left(\mathrm{R}^{2}\right)$ of the existing dependent variable.

Table 7: Dependent Variable $\mathrm{R}^{2}$ Value

\begin{tabular}{ll}
\hline & R Square \\
\hline Trust & 0.729 \\
\hline Loyalty & 0.546 \\
\hline
\end{tabular}

Table 7 indicated that $\mathrm{R}^{2}$ value for patient trust variable was 0,729 . Meaning, the value indicated that variations in patient trust could be explained by construct variables (service quality, corporate image, and tariff) by $72.9 \%$, while the remaining, $27.1 \%$ was influenced by other variables not included in the research model. $\mathrm{R}^{2}$ value for patient loyalty variable was 0,546 . Meaning, the value indicated that variations in patient loyalty could be explained by construct variables (service quality, corporate image, and tariff) by $54.46 \%$, while the remaining, $45.54 \%$ was influenced by other variables not included in the research model.

Evaluation of the inner model (Ghozali (2008) can also be carried out by checking the predictive relevance value $\left(\mathrm{Q}^{2}\right)$, viz. to measure how well the observed values are generated by the model including the estimated parameters. The $\mathrm{Q}^{2}$ value that is higher than zero indicated that the model had a predictive relevance value, while a $\mathrm{Q}^{2}$ value that is lower than zero indicated that the model had less predictive relevance. $\mathrm{Q}^{2}$ value obtained from the calculation is as follows.

$$
\begin{aligned}
Q^{2} & =1-\left(1-R_{1}^{2}\right)\left(1-R_{2}^{2}\right) \\
& =1-(1-0.729)(1-0.546) \\
& =0.877
\end{aligned}
$$

Based on the calculation, the $\mathrm{Q}^{2}$ value obtained was 0.877 or higher than zero, as a consequence, it could be said that the model obtained had predictive relevance.

The final step in evaluating the inner model was to evaluate the overall model unable be done in SEM-PLS. To overcome this problem, Tenenhaus et al. (2005) proposed global criteria for goodness-of-fit $(\mathrm{GoF})$ able to be used for validating the SEM-PLS model globally. The formulation proposed was as follows:

$$
G o F=\sqrt{(\overline{A V E}) *\left(\overline{R^{2}}\right)}
$$

After the calculation, the GoF obtained was 0,517. According to Tenenhaus (2004), the value of small $\mathrm{GoF}=0.1$, medium $\mathrm{GoF}=0.25$ and large $\mathrm{GoF}=0.38$. Based on the testing of $\mathrm{R}^{2}, \mathrm{Q}^{2}$ and 
GoF, it appeared that the model formed was robust that consequently the hypothesis testing could be carried out.

\section{HYPOTHESIS TESTING}

In this research, ten hypotheses were tested as previously formulated. The following Table 8 provides the results of the effect among the constructs of the intended hypothesis. In making a decision whether the hypothesis is statistically significant or not, the t-statistic value will be compared with the t-value from t-table. If the t-statistic value is higher than the t-table value, the hypothesis is statistically significant, vice versa. With a significance level of 5 percent $\alpha=0.05$ ), the t-table value was 1.96 . From the table, it can be seen that there are only five t-statistic values that are more than 1.96 (significant), namely service quality to trust, price/tariff to trust, service quality to loyalty, corporate image to loyalty, and price to loyalty.

Table 8: Path Coefficients (Mean, StDev, T-Values)

\begin{tabular}{|c|c|c|c|c|c|c|}
\hline & Coefficient & Mean & $\begin{array}{l}\text { Error } \\
\text { Standard }\end{array}$ & T-Stat. & P-Value & Decision \\
\hline$\underset{\substack{\text { Service } \\
\text { Trust }}}{ }$ & 0.482 & 0.451 & 0.185 & 2.605 & 0.09 & Significant \\
\hline $\begin{array}{l}\text { Corporate } \\
\rightarrow \text { Trust }\end{array}$ & -0.016 & 0.017 & 0.137 & 0.117 & 0.907 & $\begin{array}{l}\text { Not } \\
\text { significant }\end{array}$ \\
\hline Rate $\rightarrow$ Trust & 0.425 & 0.426 & 0.141 & 3.015 & 0.003 & Significant \\
\hline $\begin{array}{l}\text { Service Quality } \\
\rightarrow \text { Loyality }\end{array}$ & -0.413 & -0.412 & 0.166 & 2.494 & 0.014 & Significant \\
\hline $\begin{array}{l}\text { Corporate Image } \\
\rightarrow \text { Loyality }\end{array}$ & 0.355 & 0.362 & 0.168 & 2.113 & 0.036 & Significant \\
\hline Price $\rightarrow$ Loyalty & 0.577 & 0.571 & 0.194 & 2.968 & 0.003 & Significant \\
\hline Trust $\rightarrow$ Loyalty & 0.228 & 0.223 & 0.153 & 1.494 & 0.136 & $\begin{array}{l}\text { Not } \\
\text { significant }\end{array}$ \\
\hline
\end{tabular}

\section{MEDIATION TEST}

Causal and outcome variables. Once the influence between two variables is established, it is common for researchers to consider the role of other variables relevant to this influence. The mediation test carried out in this research was using the formulation of Baron and Kenny (1984). The first mediation analysis carried out was whether there was a significant effect of service quality on consumer loyalty mediated by trust or not. Figure 4 below shows the effect generated by SEM-PLS.

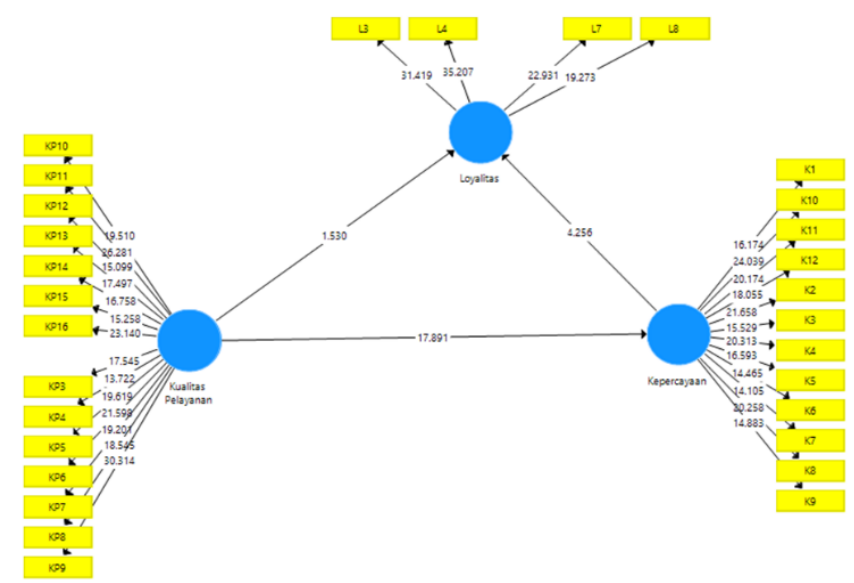

Figure 4: The Effect of Service Quality on Consumer Loyalty with Mediated Trust 
It can be said that the consumer trust variable mediates the influence between service quality and consumer loyalty, if the influence of the service quality variable on the consumer trust variable is significant, and the influence of the consumer trust variable on consumer loyalty is also significant.

Table 9 below shows the results of the mediation test estimation between service quality and consumer loyalty with the mediator variable consumer trust. From the table it can be said that consumer trust cannot mediate the effect of service quality on consumer loyalty.

Table 9: Path Coefficients of Service Quality-Loyalty with Trust Mediator

\begin{tabular}{|c|c|c|c|c|c|c|}
\hline & Coefficient & Mean & $\begin{array}{l}\text { Error } \\
\text { Standard }\end{array}$ & T-Statistics & $\begin{array}{l}P \text { - Value } \\
\alpha=0.05\end{array}$ & Decision \\
\hline & \multicolumn{6}{|c|}{ Without Mediator } \\
\hline \multirow{2}{*}{$\begin{array}{l}\text { Service } \\
\rightarrow \text { Loyalty }\end{array}$} & 0.407 & 0.410 & 0.097 & 4.196 & 0,000 & Significant \\
\hline & \multicolumn{6}{|c|}{ With Mediator } \\
\hline $\begin{array}{l}\text { Service } \\
\rightarrow \text { Loyalty }\end{array}$ & 0.164 & 0.163 & 0.103 & 1.587 & 0.113 & $\begin{array}{l}\text { Not } \\
\text { significant }\end{array}$ \\
\hline 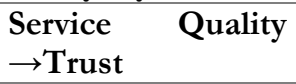 & 0.821 & 0.822 & 0.046 & 17.741 & 0,000 & Significant \\
\hline Trust $\rightarrow$ Loyalty & 0.495 & 0.500 & 0.115 & 4.290 & 0,000 & Significant \\
\hline
\end{tabular}

The next mediation analysis is whether there is a significant influence of the corporate image variable on consumer loyalty mediated by the consumer trust variable or not. The consumer trust variable can mediate the effect of the corporate image variable on consumer loyalty, if the effect of the corporate image variable on the consumer trust variable is significant, and the effect of the consumer trust variable on consumer loyalty is also significant.

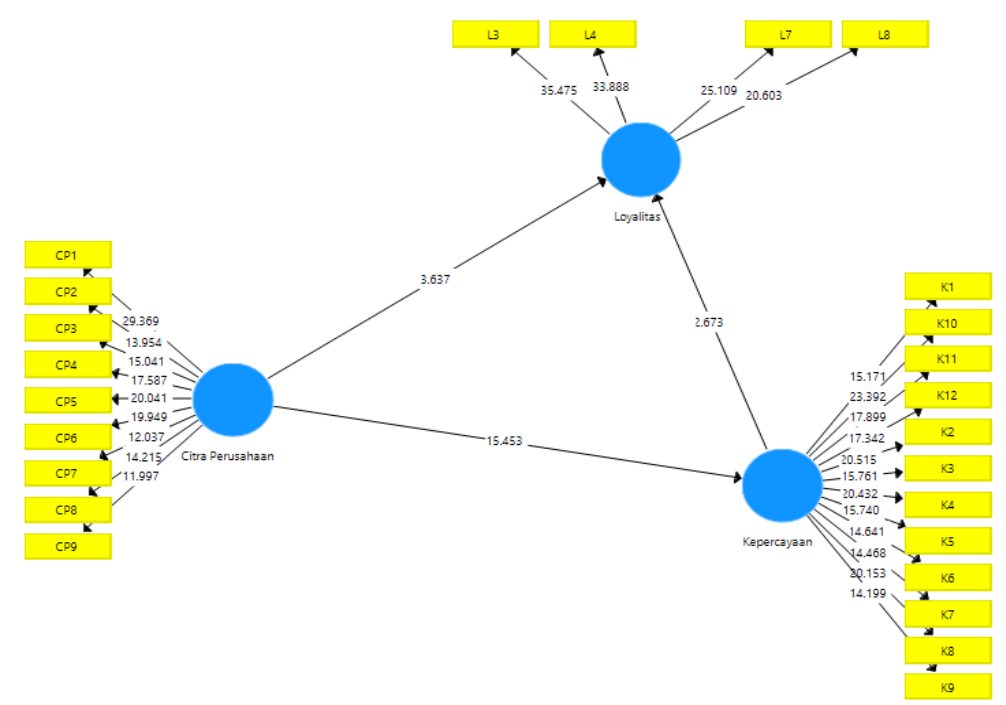

Figure 5: The effect of Corporate Image on Consumer Satisfaction with Mediated Trust

Table 10: Path Coefficients of Corporate Image-Loyalty with Trust Mediator

\begin{tabular}{lllllll} 
& Coefficient & Mean & $\begin{array}{l}\text { Error } \\
\text { Standard }\end{array}$ & T-Statistics & $\begin{array}{l}\text { P-Value } \\
\boldsymbol{\alpha}=\mathbf{0 . 0 5}\end{array}$ & \\
\hline & Without Mediator & & & & \\
\hline Corporate Image & 0.262 & 0.261 & 0.100 & 2.630 & 0.009 & Significant \\
\hline
\end{tabular}


Determinant of Customer of Loyalty in Healthcare Industry : Mediating Role of Customer Trust Mubarok, Kurniawan, Hidayat, Hia, Bandawaty

\begin{tabular}{|c|c|c|c|c|c|c|}
\hline \multicolumn{7}{|l|}{$\rightarrow$ Loyalty } \\
\hline \multicolumn{7}{|c|}{ With Mediator } \\
\hline $\begin{array}{l}\text { Corporate Image } \\
\rightarrow \text { Loyalty }\end{array}$ & 0.375 & 0.382 & 0.103 & 3.637 & 0.000 & Significant \\
\hline $\begin{array}{l}\text { Corporate Image } \\
\rightarrow \text { Trust }\end{array}$ & 0.767 & 0.770 & 0.050 & 15.453 & 0.000 & Significant \\
\hline Trust $\rightarrow$ Loyalty & 0.342 & 0.340 & 0.128 & 2.673 & 0.008 & Significant \\
\hline
\end{tabular}

Table 10 shows the estimation results of mediation test between the corporate image on consumer loyalty and consumer trust as the mediator variable. From the table it can be said that consumer trust can mediate the effect of corporate image on consumer loyalty.

The last mediation analysis is whether there is a significant effect of the tariff variable on consumer loyalty by being mediated by the consumer trust variable or not. Figure 6 below shows the effect generated by SEM-PLS.

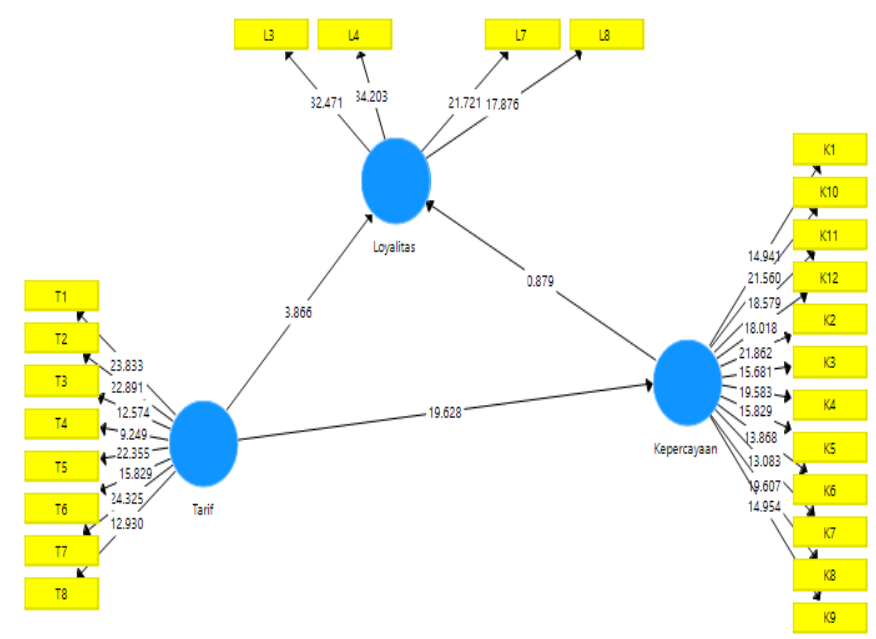

Figure 6: The effect of Tariff on Consumer Loyalty with Mediated Trust

It can be said that the consumer trust variable can mediate the effect of tariff variable on consumer loyalty, if the effect of the price/tariff variable on the consumer trust variable is significant, and the effect of the consumer trust variable on consumer loyalty is also significant. Table 11 shows the estimation results of mediation test between the tariff variable on consumer loyalty with the mediator variable of consumer trust. From the table it can be said that consumer trust cannot mediate the effect of price/tariff variable on consumer loyalty.

Table 11: Path Coefficients of Tariff-Consumer Loyalty with Trust Mediator

\begin{tabular}{|c|c|c|c|c|c|c|}
\hline & Coefficient & Mean & $\begin{array}{l}\text { Error } \\
\text { Standard }\end{array}$ & T-Statistics & $\begin{array}{l}P \text {-Value } \\
\alpha=0.05\end{array}$ & Decision \\
\hline & \multicolumn{6}{|c|}{ No Mediator } \\
\hline \multirow[t]{2}{*}{ Tariff $\rightarrow$ Loyalty } & 0.123 & 0.129 & 0.141 & 0.869 & 0.385 & Not significant \\
\hline & \multicolumn{6}{|c|}{ With Mediator } \\
\hline Tariff $\rightarrow$ Loyalty & 0.591 & 0.583 & 0.153 & 3.866 & 0.000 & Significant \\
\hline Tariff $\rightarrow$ Trust & 0.813 & 0.815 & 0.041 & 19.628 & 0.000 & Significant \\
\hline $\begin{array}{l}\text { Trust } \\
\rightarrow \text { Loyality }\end{array}$ & 0.151 & 0.159 & 0.172 & 0.879 & 0.380 & Not significant \\
\hline
\end{tabular}




\section{CONCLUSION}

In accordance with the purpose of this research, which was to examine the effect of service quality, corporate image, and rate/tariff on trust, the results of this research were formulated into the following several conclusions:

1. Service quality and rate/tariff had a significant effect on patient trust. However, clinic image did not have a significant effect on patient trust.

2. Service quality, clinic image and rate/tariff had a significant effect on patient loyalty. However, trust did not have a significant effect on patient loyalty.

3. Trust can mediate the effect of clinical image on patient loyalty. However, trust cannot mediate the effect of service quality and rate/tariff on patient loyalty.

4. The strength values of dependent variable shown by the calculation results of the multiple correlation squared $\left(\mathrm{R}^{2}\right)$ value of both trust and patient loyalty were significant.

The results of this research disclosed that the quality of service and rate/tariff had a significant effect on patient trust and corporate image had no significant effect. The quality of service, clinic image and price/tariff had a significant effect on patient loyalty, while trust had no significant effect. It was also revealed that only clinic image that trust could be mediated by the effect on patient loyalty, while service quality and price/tariff could not be mediated.

Therefore, the results of this research can provide some managerial implications in clinical management practice, they are:

1. Service quality is a key factor for the success of the clinic business, because it can have positive implications for creating patient trust and loyalty. Therefore, the availability of an excellent service program is a key factor for the success of the clinic business. All employees at the clinic are required to be actively involved in the implementation of the excellent service program. For the management, it is necessary to organize service educations in the form of training for doctors, nurses, and non-medical officers. Clinics also need to make minimum service standards that are continuously updated in line with patient demands. This means that continuous improvement must be made. Therefore, the concept of integrated quality management is appropriate to be implemented for the improvement of every clinical work process.

2. The image of the clinic is also a determinant factor in fostering patient trust and loyalty. The efforts for building a positive image are to improve the implementation of corporate social responsibility activities, such as free medical treatment with health counseling, joint exercises or getting involve in the medical team of disaster. In addition, balancing the business and social orientation in clinic operations is also an effort for building a positive image. Clinics should be able to show a strong social spirit, to treat patients fairly and professionally regardless of their different economic levels, no discrimination.

3. Price/tariff determine the creation of trust and loyalty, that as a consequence, in determining them, the prices/tariffs must be competitive and also be followed by improving the quality of pleasant services. Increased prices/tariffs along with improved service quality can make consumers happy during the treatment, that consequently, it can encourage patient trust and loyalty.

4. Although the trust variable in this research does not have a significant effect on loyalty, clinics must seek efforts to build commitment and responsibility for health services so that 
the patients will trust them. Clinics must keep all service promises they have made, because the fulfillment of every promise determines the patient trust towards the clinics. Failure to keep promises will give clinics the risk of losing the patient's trust. Trust always affects two factors-speed and cost. As trust increases, speed will increase and costs will decrease. Conversely, when trust decreases, speed will decrease and costs will increase. All parties involved in the service must be

\section{REFERENCE}

Baliga, A. J., Chawla, V., Sunder M, V., Ganesh, L. S., \& Sivakumaran, B. (2021). Service Failure and Recovery in B2B Markets - A Morphological Analysis. Journal of Business Research, 131, 763-781. https://doi.org/10.1016/j.jbusres.2020.09.025

Cachero-Martínez, S., \& Vázquez-Casielles, R. (2021). Building consumer loyalty through eshopping experiences: The mediating role of emotions. Journal of Retailing and Consumer Services, 60, 102481. https://doi.org/10.1016/j.jretconser.2021.102481

Chang, E.-C., Lv, Y., Chou, T.-J., He, Q., \& Song, Z. (2014). Now or later: Delay's effects on post-consumption emotions and consumer loyalty. Journal of Business Research, 67(7), 13681375. https://doi.org/10.1016/j.jbusres.2013.08.016

Chi, O. H., Jia, S., Li, Y., \& Gursoy, D. (2021). Developing a formative scale to measure consumers' trust toward interaction with artificially intelligent (AI) social robots in service delivery. Computers in Human Behavior, 118, 106700. https://doi.org/10.1016/j.chb.2021.106700

Coelho, P. S., Rita, P., \& Santos, Z. R. (2018). On the relationship between consumer-brand identification, brand community, and brand loyalty. Journal of Retailing and Consumer Services, 43(5), 101-110. https://doi.org/10.1016/j.jretconser.2018.03.011

Dewani, P. P., Sinha, P. K., \& Mathur, S. (2016). Role of gratitude and obligation in long term customer relationships. Journal of Retailing and Consumer Services, 31, 143-156. https://doi.org/10.1016/j.jretconser.2016.01.005

Dewsnap, B., Micevski, M., Cadogan, J. W., \& Kadic-Maglajlic, S. (2020). Flexibility in marketing \&amp; sales interfacing processes. Industrial Marketing Management, 91, 285-300. https://doi.org/10.1016/j.indmarman.2020.09.005

Dugar, A., \& Chamola, P. (2021). Retailers with traits of consumer: Exploring the existence and antecedents of brand loyalty in small unorganized retailers. Journal of Retailing and Consumer Services, 62, 102635. https://doi.org/10.1016/j.jretconser.2021.102635

Ghaliyah, D., \& Mubarok, E. S. (2017). The Influence of Service Quality, Hospital Image, and Promotions to Patients' Trust and Loyalty. European Journal of Business and Management, 9(20), 86-97. https://www.iiste.org/Journals/index.php/EJBM/article/view/37814

Hallikainen, H., \& Laukkanen, T. (2018). National culture and consumer trust in e-commerce. International Journal of Information Management, 38(1), 97-106. https://doi.org/10.1016/j.ijinfomgt.2017.07.002

Hartmann, M., Klink, J., \& Simons, J. (2015). Cause related marketing in the German retail sector: Exploring the role of consumers' trust. Food Policy, 52, 108-114. https://doi.org/10.1016/j.foodpol.2014.06.012

Kaur, D., Mustika, M. D., \& Sjabadhyni, B. (2018). Affect or cognition: which is more 
influencing older adult consumers' loyalty? Heliyon, 4(4), e00610.

https://doi.org/10.1016/j.heliyon.2018.e00610

Kim, C. E., Shin, J.-S., Lee, J., Lee, Y. J., Kim, M., Choi, A., Park, K. B., Lee, H.-J., \& Ha, I.-H. (2017). Quality of medical service, patient satisfaction and loyalty with a focus on interpersonal-based medical service encounters and treatment effectiveness: a crosssectional multicenter study of complementary and alternative medicine (CAM) hospitals. BMC Complementary and Alternative Medicine, 17(1), 174. https://doi.org/10.1186/s12906017-1691-6

Kopaneli, A. (2014). Finance, Marketing, Management and Strategy Planning. A Qualitative Research Method Analysis of Case Studies in Business Hotels in Patras and in Athens. Procedia Economics and Finance, 9, 472-487. https://doi.org/10.1016/S2212-5671(14)00049-5

Kotler, P., \& Keller, K. L. (2016). Marketing Management (15th ed.). Pearson Education, Inc. https://www.pearson.com/us/higher-education/product/Kotler-Marketing-Management15th-Edition/9780133856460.html

Kurnianingrum, A. F., \& Hidayat, A. (2020). The Influence of Service Quality and Price Perception on Cunsumer Trust and Revisit Intention at Beauty Care Clinic in Indonesia. Archives of Business Research, 8(6), 268-281. https://doi.org/10.14738/abr.86.8489

Kusumawardani, D. A., Fitriasari, N., \& Linda, L. E. (2020). The Satisfaction of health care products forming inpatients loyalty in Melati Husada Hospital Malang. Enfermería Clínica, 30, 188-191. https://doi.org/10.1016/j.enfcli.2020.06.042

Lee, C. K. H., \& Wong, A. O. M. (2021). Antecedents of consumer loyalty in ride-hailing. Transportation Research Part F: Traffic Psychology and Behaviour, 80, 14-33. https://doi.org/10.1016/j.trf.2021.03.016

Louis, D., Lombart, C., \& Durif, F. (2021). Packaging-free products: A lever of proximity and loyalty between consumers and grocery stores. Journal of Retailing and Consumer Services, 60, 102499. https://doi.org/10.1016/j.jretconser.2021.102499

Minarti, S. N., \& Segoro, W. (2014). The Influence of Customer Satisfaction, Switching Cost and Trusts in a Brand on Customer Loyalty - The Survey on Student as im3 Users in Depok, Indonesia. Procedia - Social and Behavioral Sciences, 143, 1015-1019. https://doi.org/10.1016/j.sbspro.2014.07.546

Möller, K., \& Parvinen, P. (2015). An impact-oriented implementation approach in business marketing research. Industrial Marketing Management, 45, 3-11. https://doi.org/10.1016/j.indmarman.2015.02.025

Mubarok, E. S. (2019). The effect of service quality, corporate image, promotion on patient satisfaction within indonesian hospital industry. International Journal of Multidisciplinary Research and Development, 6(12), 136-143.

https://www.iiste.org/Journals/index.php/EJBM/article/viewFile/37814/38897

Nosi, C., D’Agostino, A., Pratesi, C. A., \& Barbarossa, C. (2021). Evaluating a social marketing campaign on healthy nutrition and lifestyle among primary-school children: A mixedmethod research design. Evaluation and Program Planning, 89, 101965. https://doi.org/10.1016/j.evalprogplan.2021.101965

Olson, E. M., Olson, K. M., Czaplewski, A. J., \& Key, T. M. (2021). Business strategy and the management of digital marketing. Business Horizons, 64(2), 285-293.

https://doi.org/10.1016/j.bushor.2020.12.004 
Olson, E. M., Slater, S. F., Hult, G. T. M., \& Olson, K. M. (2018). The application of human resource management policies within the marketing organization: The impact on business and marketing strategy implementation. Industrial Marketing Management, 69, 62-73. https://doi.org/10.1016/j.indmarman.2018.01.029

Ozdemir, S., Zhang, S., Gupta, S., \& Bebek, G. (2020). The effects of trust and peer influence on corporate brand-Consumer relationships and consumer loyalty. Journal of Business Research, 117, 791-805. https://doi.org/10.1016/j.jbusres.2020.02.027

Prentice, C., \& Correia Loureiro, S. M. (2017). An asymmetrical approach to understanding configurations of customer loyalty in the airline industry. Journal of Retailing and Consumer Services, 38, 96-107. https://doi.org/10.1016/j.jretconser.2017.05.005

Rizan, M., Setyaningsih, R., \& Saidani, B. (2016). The Influence of Service Quality and Price toward Trust and Its Impact on Customer Loyalty of Low Cost Carrier Indonesia. JRMSI Jurnal Riset Manajemen Sains Indonesia, 7(1), 176-196. https://doi.org/10.21009/JRMSI.007.1.10

Ruiz-Real, J. L., Uribe-Toril, J., \& Gázquez-Abad, J. C. (2020). Destination branding: Opportunities and new challenges. Journal of Destination Marketing \& Management, 17, 100453. https://doi.org/10.1016/j.jdmm.2020.100453

Sanjeev, M. A. (2017). Impact of Individual and Employment Variable on Job Satisfaction \&amp; Turnover Intention among Sales and Marketing Professionals. Procedia Computer Science, 122, 55-62. https://doi.org/10.1016/j.procs.2017.11.341

Shi, X., Lin, Z., Liu, J., \& Hui, Y. K. (2018). Consumer loyalty toward smartphone brands: The determining roles of deliberate inertia and cognitive lock-in. Information \& Management, 55(7), 866-876. https://doi.org/10.1016/j.im.2018.03.013

To, W. M., Martin, E. F., \& Yu, B. T. W. (2015). Effect of management commitment to internal marketing on employee work attitude. International Journal of Hospitality Management, 45, 14 21. https://doi.org/10.1016/j.ijhm.2014.11.002

Tseng, T. H., \& Lee, C. T. (2018). Facilitation of consumer loyalty toward branded applications: The dual-route perspective. Telematics and Informatics, 35(5), 1297-1309. https://doi.org/10.1016/j.tele.2018.03.002

White, C. J., \& Tong, E. (2019). On linking socioeconomic status to consumer loyalty behaviour. Journal of Retailing and Consumer Services, 50, 60-65. https://doi.org/10.1016/j.jretconser.2019.05.001

Yucel-Aybat, O., \& Hsieh, M.-H. (2021). Consumer mindsets matter: Benefit framing and firmcause fit in the persuasiveness of cause-related marketing campaigns. Journal of Business Research, 129, 418-427. https://doi.org/10.1016/j.jbusres.2021.02.051

Zeithaml, V., Bitner, M. J., \& Gremler, D. (2018). Services Marketing: Integrating Customer Focus Across the Firm (7th ed.). McGraw-Hill. https://www.mheducation.com/highered/product/services-marketing-integratingcustomer-focus-across-firm-zeithaml-bitner/M9780078112102.toc.html 